\title{
The Value of Islamic Education in Local Wisdom Traditions in Central Java
}

\author{
Leli Nisfi Setiana ${ }^{1,}$ Evi Chamalah ${ }^{2}$ \\ Universitas Islam Sultan Agung ${ }^{1,2}$ \\ \{lelinisfi@unissula.ac.id ${ }^{1}$,chamalah@unissula.ac.id $\left.{ }^{2}\right\}$
}

\begin{abstract}
The purpose of this study is to describe the symbolic meaning and value of Islamic education in the local wisdom tradition in Central Java. In Islamic education it means that someone who already knows religious teachings can then practice them in everyday life. The local wisdom of an area can be a medium for interpreting the values of Islamic education which are not necessarily obtained in formal education. This research is a qualitative descriptive study with a literary semiotic approach. This study uses three techniques, namely note-taking techniques, observation techniques and documentation techniques. The results of this study are in the form of describing the symbolic meaning in the local wisdom tradition of mendak, padusan, lebaran kupat, sadran, selikuran, muludan, ngapati, dugderan in Central Java, and describing the value of Islamic education, namely the value of education in the local wisdom tradition in Central Java.
\end{abstract}

Keywords: Islamic Education Values, Local Wisdom Traditions

\section{Introduction}

Humans and education are two things that are closely related, because from birth until death, humans are always involved in the educational process. In this context education has a broad meaning, namely learning activities to know, know, think, understand, consider, decide and do actions in accordance with norms and rules. It is through the educational process that humans are able to do or act properly and correctly. Humans with common sense make education a basic foundation in achieving a good life based on religious norms and guidance. Islamic teachings base their teachings on the teachings of God contained in the Qur'an, and the teachings of the Prophet Muhammad SAW contained in his hadith (speech, deeds and decrees), also based on the opinion of a healthy mind which does not contradict the teachings of the Qur'an. 'an and al-Hadith. Thus humans can also maintain, maintain and practice the teachings produced by experts, religious leaders, researchers, intellectuals through studies, research and so on. Islamic education guards mankind in the process of changing their lives from one stage to another in a balanced manner, and straightens those who are still at the previous stage, namely by means of tauhid, noble morals and balance.With regard to the implementation of national education, the state has a huge mandate to prepare educated human beings in order to organize the future of the nation's life. 
In Islamic education, there are various values that support the implementation of education. This value becomes the basis for mental development so that it can provide output for education in accordance with the expectations of the wider community. The main principles of Islamic education values that must be instilled in children are the value of i'tiqodiyah education, the value of amaliyah education, the value of khuluqiyah education (Achmadi, 1992: 58)[1]. First, I'tiqodiyah Education Values are values related to faith such as faith in Allah SWT, angels, messengers, books, the last day and destiny which aims to organize individual beliefs. Iman comes from Arabic with the basic word amanayu'minu imanan which means to believe or believe (Kaelani HD, 2000: 58)[3]. To believe in Indonesian means to admit or believe that something (which is believed) is true or real. In faith, there are 3 elements that must work in harmony, there should not be an overlap between verbal confession, justification of the heart and actual implementation in action. Second, the Amaliyah Education Value is a value related to behavior. The value of amaliyah education includes (a) Worship Education, which is clear evidence for a Muslim in believing and adhering to Islamic aqidah, (b) The value of Amaliyah education is a value related to behavior. The value of amaliyah education is worship education, muamalah education (Syakhsiyah education, Madaniyah education, Jana'iyah education, Murafa'at education, Dusturiyah education, Duwaliyah education, Iqtishadiyah education).

The three Khuluqiyah Education Values are education related to ethics (morals) which aims to rid oneself of low behavior and decorate oneself with praiseworthy behavior. Moral education is the most important part of everyday life, because someone who has no morals will make himself do harm to others [1]. Based on this definition, it can be concluded that the values of Islamic education consist of three pillars, namely the value of i'tiqodiyah education, the value of amaliyah education, the value of khuluqiyah education which comes from the AlQur'an and Hadith so that humans can be practiced by humans to become devout and noble people.

Local wisdom according to Magdalia Alfian (2013: 428) is defined as a view of life and knowledge as well as a life strategy in the form of activities carried out by local people in meeting their needs [5]. Astria (2013: 111) has the view that local wisdom is a conceptual idea that lives in society, grows and develops continuously in people's consciousness from being related to sacred life to profane (daily part of life and its ordinary nature). - just normal) [6]. Based on these two sources, it can be concluded that the local wisdom of a life view emerges from a conceptual notion that grows and takes place continuously by the local community. Local wisdom becomes an oasis in order to increase one's knowledge and become a medium for education outside of formal education. Islamic education, whose knowledge is based on the Quran can be used as a guide in people's daily lives. When human behavior is far from being guided by religion, Islamic education becomes very important in order to improve faith and impact in all forms of life. There are various forms of wisdom in Central Java, including the tradition of mendak, amaliyah, sadran, blackjack, mauled prophet (Muludan) ceremony, ngapati, dugderan, and Eid kupat. Each local wisdom has the characteristics and philosophies of different regions, but the goal is the same, namely to strengthen the relationship in society. The difference in characteristics in local wisdom does not create a division but can provide variations so that it is interesting to study.

Based on this, the authors conducted a study entitled " The Value of Islamic Education in Local Wisdom Traditions in Central Java" There are three formulations in this study, namely (1) what is the form of symbolic meaning in the local wisdom tradition in Central Java, (2) what is the form of implementation of Islamic education through the local wisdom tradition in Central Java. The objectives of this study are (1) to describe the symbolic meaning in the local 
wisdom tradition in Central Java, (2) to describe the implementation of Islamic education through the local wisdom tradition in Central Java. Research on literacy and critical literacy has been conducted by several experts, including Dian (2014)[7], Kastolani (2016)[4], Kuntowijoyo(1995)[5], Roqib (2009)[8],W.J.S Poerwadinata (1982)[15]. The similarity between the author's research and the research that has been done is the similarity of the local wisdom traditions that exist in Central Java. The difference in research lies in the type of object under study, namely the research of experts uses only one object, while this research uses many objects of study of local wisdom in Central Java.

\section{Methods}

The method used in this research is descriptive qualitative. According to Sugiyono (2015) qualitative research is a study that uses the philosophical basis of postpositivism to identify natural objects In this connection[11]. Researchers also use the theory from Sukmadinata, suggesting that qualitative research is used by researchers to understand social phenomena that exist in society [12]. So it can be seen together that the key instrument of this research is social phenomena, namely local wisdom, local wisdom traditions that exist in Central Java. The data from this study are in the form of words, phrases, clauses, and sentences contained in local wisdom traditions in Central Java. Sources of data in this study are primary and secondary sources. The primary data source in this study is the text of local wisdom traditions in Central Java which includes the traditions of mendak, padusan, lebaran kupat, sadran, selikuran, muludan, ngapati, dugderan. Secondary data sources in this study are supporting data from various relevant sources such as the internet and journals related to local wisdom traditions in Central Java. Data collection techniques in this study consisted of (1) recording techniques, (2) shooting techniques, (3) observation, (4) recording, (5) interviews, (6) questionnaires. There are limitations in the realm of this research so that researchers only use three techniques, namely interview techniques, observation techniques, and note-taking techniques. First, interview techniques are used to document all things related to research, namely from community leaders. Second, the observation technique in this technique, the researcher does two things, namely being present in person and looking at the youtube channel of local wisdom traditions in Central Java in order to observe and study, see the existence of the research object. Finally, the technique of note-taking, in this technique the researcher notes things that are contained in the local wisdom tradition in Central Java.

This study applies data analysis techniques through several stages. The analysis technique in this study uses sources from Sulistyorini and Eggy, namely (1) data collection, (2) data classification, (3) data interpretation, (4) data classification, (5) data interpretation, and (6) data inference[13]. In data collection techniques, researchers collect data that contain symbolic meanings of Islamic education values. In data classification techniques, classification of the data obtained is carried out. In data interpretation techniques, data collection has been classified and interpreted by providing an interpretation of the meaning in accordance with the research problem. In the data classification technique, existing data are grouped with activities in the form of reading the traditional text of local wisdom in Central Java intensively to obtain a complete picture, linking the data that has been found with the criteria that have been made in accordance with the formulation of the problem and entering the data into categories..In the data interpretation technique, it is carried out by analyzing the classification of the data that has been collected in accordance with the problem under study. The last technique is data inference, which is data that has been interpreted and then described in the form of exposure to 
the results of the analysis. The approach in this research is to use a semiotic approach regarding codes, symbols of symbols, meanings and signs found in the local wisdom tradition in Central Java.

\section{Result and Discussion}

Central Javanese (Semarang) traditional ceremony, the picture and explanation is one of the information related to Indonesian indigenous culture that must receive attention from the community and government. Chaca (2018) Central Javanese traditional ceremonies are usually held for various community celebrations, some for weddings, thanksgiving or avoiding reinforcements[14]. Starting from their personal nature to common interests. Some of the traditional ceremonies in Central Java have survived until now and some are no longer used by the community. Over time, this tradition has become foreign because it was not passed on to the next generation.

\subsection{Symbolic Meaning in the Local Wisdom Tradition in Central Java}

\section{a) Mendak Ceremony}

Mendak Death Ceremony which originates from Central Java. In Indonesian, Mendak Kematian is commemorating death after one year. Actually, not only that in Javanese customs such as Mitoni (seven days after death). Actually, not only that in Javanese customs such as Mitoni (seven days after death). Mendak is commonly practiced by people who believe that prayers offered at the mendak event will be conveyed to the spirit. However, not all Muslim communities, in particular, hold mendak events because they are related to the community's beliefs.

\section{b) Padusan}

The Padusan ceremony is intended to welcome the holy month of Ramadan. Padusan itself comes from the word Adus which means "to bathe" and "to clean up". The Padusan tradition is carried out by bathing together where local residents will bathe and purify themselves both body and soul in order to welcome the coming of the month of Ramadan in their lives they live. Some say that Padusan is one of the cultural heritage of Walisongo when they spread Islamic teachings by marrying it with Javanese culture which was then dominated by Hindu culture.

\section{c) Ketupat Lebaran}

Ketupat Lebaran was held on the 8th of Shawwal. The day on which the fasting of Shawwal for 6 days ends. Fasting on these six days in the month of Shawwal is the sunnah of the Prophet Muhammad. Ketupat is a symbol of togetherness and a symbol of affection. In Javanese tradition, there are various forms of ketupat. The term ketupat has its own meaning. Ketupat or Kupat comes from the Javanese term, "confess fast" or confess wrong. The procession of admitting mistakes is generally implemented in the Sungkeman tradition. The child knelt down to apologize to his parents. The tradition of Sungkeman is also a place for 
self-learning to understand the importance of respecting parents, not being arrogant towards them and always looking forward to their blessings and guidance.

\section{d) Sadran (Nyadran)}

This point is Nyadran. This Central Javanese tradition is a ceremony performed by the Javanese people to welcome the holy month of Ramadan. It should be noted, before the existence of Islam Nyadran was a Hindu-Buddhist tradition. And since the existence of Walisongo in Java, the Sunan spread Islam by combining and rectifying these traditions. In order to be easily accepted by people who still adore the spirit that in Islam is polytheistic. The sunan replace their prayers and recitations from the Qur'an even though they clash with Javanese tradition. Over time, the Javanese finally accepted and practiced it.

\section{e) Selikuran}

Selikuran is a ceremony that applies in Central Java. The night of the 21 st Ramadan is the time for this tradition. Javanese people in the local area usually do a prayer together led by a religious figure who has a mandate. Knowing what it means, Selikur in Javanese has a very special meaning. Time to get closer to Allah SWT and pray for Muslims who have preceded him. The local Javanese people regard this custom as a sense of their love for Islam and the Prophet Muhammad.

\section{f) The Prophet's Birthday Ceremony (Muludan)}

The Prophet's Birthday ceremony or tradition also applies in Central Java. Muludan or the prophet's maulid which in Javanese tradition has the meaning of the anniversary of the birth of the prophet Muhammad Saw and the celebration is every 12th of Rabiul Awal. The tradition of celebrating the birthday of the prophet Muhammad Saw does not only apply in Central Java. Other areas such as North Sumatra, many Muslims also practice it. It's just that in an orderly event adapted to the customs prevailing in the local area.

\section{g) Ngapati}

The Ngapati ceremony is when a pregnant woman has reached 4 months of pregnancy. Usually, Javanese people do this event because at the age of 4 months the fetus will be given life by Allah SWT so that the Javanese will pray for it. And as gratitude for the gifts that have been given in the Ngapati way. During the Ngapati process, namely praying together so that later when he is born he will be a useful person and away from religious prohibitions.

\section{h) Dugderan}

Dugderan is a traditional ceremony performed by residents of Semarang City (Central Java) to welcome the holy month of Ramadan. This tradition begins with the beating of the drum that reads "dug dug dug", then greeted with the sound of the cannon boom "der" so that the local people named it Dugderan. The following is a further explanation of the two research results based on the object of study in the study. 


\subsection{The value of Islamic education in the local wisdom tradition in Central Java}

a) I'tiqodiyah Education Values are values related to faith such as faith in Allah SWT, Angels, Messengers, Books, the Last Day and Destiny which aims to organize individual beliefs

Mendak ceremony, in the tradition of the mendak ceremony, contains the meaning that the activity of praying for the soul of a person who has died is on the seventh and thousandth day of his death. That death must indeed be believed with a sense of faith because it will be experienced by mankind, so that while we are alive remember to die and prepare for acts of worship while still in the world.

\section{b) Amaliyah Educational Value is a value related to behavior}

a) The padusan tradition contains meaning in order to welcome the arrival of the holy month of Ramadan, several groups of local people in an area do bathing activities either in a river or a pool of water in which water flows from mountain springs etc. Bathing and cleaning activities are carried out with the intention of purifying both body and soul.

b) The Sadran tradition is included in the category of amaliyah educational values. Where the Sadran tradition is carried out by welcoming the holy month of Ramadan in the form of people's behavior by reading prayers and reciting Al Qu'ran with the hope of returning to a pure heart in carrying out fasting.

c) The Selikuran tradition is included in the value of amaliyah education. A tradition that takes the form of a 21 night ceremony (in Javanese it is called selikur). Even though it is in the form of amaliyah educational values related to behavior for people who believe in it, it can integrate one's faith. When an ordinary person performs a good habit, namely blackjack, the effect is to increase the sense of faith that death exists and will be experienced by all mankind.

d) Prophet's Birthday Ceremony (Muludan), It is very clear that the Prophet's Birthday Ceremony (Muludan) is included in the value of amaliyah education. As for the form of Muludan behavior carried out in Javanese customs in Central Java and in North Sumatra with the same meaning but the technical implementation is different in each region.

e) Ngapati, One of the traditions in Javanese society that contains the value of amaliyah education is included in human behavior in the form of the tradition of inviting relatives and neighbors in the neighborhood to read prayers for the future baby who is four months old in the womb. Because it is explained in Al-Qu'ran that Allah sent down revelations in the form of life and destiny to live at the age of four months, which is while still in the womb of his mother.

f) The dugderan tradition is included in the category of traditional amaliyah education values that are often awaited by people in Semarang and become a forum for friendship between traders and buyers because they can come from inside and outside the city of Semarang. The meaning contained in the Dugderan tradition is the drum sounded as the beginning of welcoming the arrival of the holy month of Ramadan, the community rejoices by sounding the cannon royally, the hope is that in carrying out the fasting month vigorously wins victory on Eid al-Fitr. 


\section{c) Khuluqiyah Education Value is education related to ethics (morals) which aims to rid oneself of low behavior and decorate oneself with praiseworthy behavior}

Eid Kupat Become one of the iconic traditions in Kudus and several other areas in Central Java. Eid Kupat is held after Idul Fitri. Ketupat has a philosophy of symbol of togetherness and a symbol of love in the traditions of Javanese society. Meanwhile, the term ketupat in Javanese is confessing fast or admitting one's mistakes which is implemented in the form of sungkeman. The value of Islamic education that is formed is the value of khuluqiyah education related to the sungkeman ethic in the Eid Kupat tradition, where the younger parties apologize and kneel in front of older people, with the aim of cleaning themselves from bad behavior and decorating themselves with praiseworthy behavior, namely forgiving each other.

\section{Conclusion}

a) Symbolic Meaning The local wisdom tradition in Central Java has a religious symbol. Religiosity in the local wisdom tradition is implied and expressed in the form of prayers, traditional ceremonies, hospitality and bathing in holy water. Each local wisdom tradition in Central Java has different characteristics and meanings. The type of mendak wisdom is included in the category of the tradition of reading prayers, the padusan tradition in the category of purifying oneself, the local wisdom of Eid kupat which is included in the category of establishing friendship and local wisdom sadran, selikuran, maulud Nabi ceremony (Muludan), ngapati and dugderan traditional ceremonies in Javanese society.

b) The Value of Islamic Education on Local Wisdom Traditions in Central Java Based on the results of data analysis, the first conclusion is the form of implication of the value of Islamic education I'tiqodiyah, there is the mendak tradition where the main focus of the local wisdom tradition is about the faith of the Javanese people which is symbolically implied. Second, the implications of the value of Amaliyah education in the traditions of sadran, blackjack, mauled Nabi (Muludan), ngapati, and dugderan ceremonies, namely the main focus is related to the behavior implicit in the traditions in society. Third, the implications of the value of Khuluqiyah Islamic education on the Eid Kupat tradition, the main focus is related to cleaning oneself and trying to be human beings who have commendable morals in society.

\section{References}

[1] Achmadi. Islam Sebagai Paradigma Ilmu Pendidikan. Yogyakarta: Adytia. (1992).

[2] Astria, Mita, Wakidi dan Muhammad Basri. .Jurnal PESAGI, Vol 1 No 5, http://jurnal.fkip.unila.ac.id/index.php/PES/article/view/3066. (2013).

[3] HD, Kaelani. Islam Dan Aspek-Aspek Kemasyarakatan. Jakarta: Bumi. Aksara. (2000)

[4] Kastolani, dalam Jurnal Kontemplasi, Vol 04 Nomor 01, https://media.neliti.com/media/publications/67299-ID-relasi-islam-dan-budaya-lokalstudi-tent.pdf. (2016).

[6] Kuntowijoyo. Pengantar Ilmu sejarah. Yogyakarta : Yayasan Bentang. (1995).

[5] Magdalia, Alfian. Potensi Kearifan Lokal dalm Pembentukan Jati Diri dan Karakter Bangsa. Prosiding The 5th International Cofereence on Indonesian Studies: "Ethnicity and Globalization". Jakarta: FIPB UI. (2013). 
[6] Nuraini, Asriati. Mengembangkan Karakter Peserta Didik Berbasis Kearifan Lokal Melalui Pembelajaran di Sekolah. Jurnal Pendidikan Sosiologi dan Humaniora. 2(III). Hlm. 106-119. (2012).

[7] Permanasari, Dian.http://eprints.uny.ac.id/20731/1/Dian\%20Permanasari\%2009209241040.pdf. (2014)

[8] Roqib, Moh. Ilmu Pendidikan IslamPengembangan Integratif di Sekolah, Keluarga, dan Masyarakat. Yogyakarta: LkiS. (2009).

[10] Sudikan, Setya Yuwana. Metode Penelitian Sastra Lisan. Surabaya:Citra Wacana Press (2001).

[11] Sugiyono. Metode Penelitian Kombinasi (Mix Methods). Bandung: Alfabeta (2015).

[12] Sukmadinata, Nana Syaodih. Metode Penelitian Pendidikan. Bandung: PT Remaja Rosdakarya (2012).

[13] Sulistyorini, Dwi dan Eggy Fajar Andalas. Sastra Lisan, Kajian Teori dan Penerapannya dalam Penelitian. Malang: Madani (2017)

[14] Tata, Chacha, Desember 1, https://www.silontong.com/2018/12/01/upacara-adat-jawatengah/\#.(2018).

[15] W.J.S Poerwadarminta. 1982. Kamus Umum Bahasa Indonesia. Jakarta: PN BALAI PUSTAKA. 